\title{
OPTIMIZATION OF ALKALINE PROTEASE PRODUCTION BY STREPTOMYCES AMBOFACIENS IN FREE AND IMMOBILIZED FORM
}

\author{
${ }^{1}$ Nayera A.M. Abdelwahed, ${ }^{1,2}$ Enas N. Danial, \\ ${ }^{3}$ Noura El-Ahmady El-Naggar and ${ }^{1}$ Asem A. Mohamed \\ ${ }^{1}$ Department of Chemistry of Natural and Microbial Products, National Research Center, 12311, Dokki, Cairo, Egypt \\ ${ }^{2}$ Department of Biochemistry, Faculty of Girls Science, King Abdulaziz University Jeddah, Saudi Arabia \\ ${ }^{3}$ Department of Bioprocess Development, Genetic Engineering and Biotechnology Research Institute, \\ City for Scientific Research and Technology Applications, Alexandria, Egypt
}

Received 2013-10-25; Revised 2013-12-27; Accepted 2013-12-28

\begin{abstract}
Optimization of alkaline protease production by Streptomyces ambofaciens NRRL 2420 in free and immobilized form was investigated using submerged fermentation technique. The optimum conditions for maximum alkaline protease production 342 unit $\mathrm{mL}^{-1}$ were $30^{\circ} \mathrm{C}$ at $\mathrm{pH} 8.5$ and incubation time $96 \mathrm{~h}$ in free cell cultures using starch $20 \mathrm{~g} \mathrm{~L}^{-1}$ as carbon source and yeast extract $5 \mathrm{~g} \mathrm{~L}^{-1}$ as nitrogen source. The incubation time for the best yield of 344 unit $\mathrm{mL}^{-1}$ was reduced to $72 \mathrm{~h}$ under the optimized fermentation conditions by immobilized cells adsorbed on synthetic cotton fibers. Data obtained during 5 reusable cycles showed higher levels of enzyme in shorter time duration. Immobilization of Streptomyces ambofaciens NRRL 2420 on synthetic cotton fiber permit repeated reuse of the cells under the optimized fermentation conditions.
\end{abstract}

Keywords: Streptomyces ambofaciens, Alkaline Protease, Immobilization, Adsorption

\section{INTRODUCTION}

Protease enzyme catalyses the hydrolysis of proteins into peptides and amino acids and considered as one of the most useful enzyme groups. Alkaline proteases have found a wide application in several industrial processes, such as laundry detergents, protein recovery or solubilization as well as in the production of protein hydrolysates, meat tenderizations, in bating of hides and skins in leather industries, for the film industry and in waste processing (Gupta et al., 2002; Amit et al., 2011). It constitute $60-65 \%$ of the global industrial market (Banerjee et al., 1999). While most of the studies on actinomycetes have focused on antibiotic production, only few reports are on their enzymatic potential (Chaphalkar and Deys, 1998; Schippers et al., 2002; Tsuchiya, 1997). The possibility of using Streptomyces for protease production has been investigated because of capacity to secrete the proteins extracellular in the media which is generally regarded as safe with food and drug administration (GRAS). Streptomyces that produce protease include $S$. clavuligerus, $S$. griseus, S. rimosus, $S$. thermoviolaceus and $S$. thermovulgaris (James et al., 1991). They produce variety of extracellular proteases that have been related to aerial mycelium formation and sporulation (Kim and Lee, 1995). Studies on Streptomyces clavuligerus cultures for protease production showed that the amount of enzyme produced varies greatly with the culture media used (Porto et al., 1996). Proteases from Streptomyces origin offer an advantage as the mycelium can be easily removed by filtration (Phadatare et al., 1993). By using immobilized cells, the protease can be produced in a shorter reaction time. Further, the rate of protease production can be improved over that of submerged batch fermentation. The long-term stability of the immobilized cells during

Corresponding Author: Nayera A.M. Abdelwahed, Departement of Chemistry of Natural and Microbial Products, National Research Center, 12311, Dokki, Cairo, Egypt Tel: (002)01224753679 Fax: (002)02 22638839 
the course of fermentation and the easy separation of enzyme also make them promising candidates for commercial exploitation. The most widely used immobilization method is entrapment, but the adsorption method has two advantages namely its simplicity and better physiological conditions (Pramod and Lingappa, 2008). Batch (Ozawa et al., 1992) and repeated batch (Ozawa et al., 1996) fermentation processes were also demonstrated using urethane foam as an immobilization carrier. As the composition of culture media strongly influences enzyme production (Giarrhizzo et al., 2007). The objective of this study was to optimize cultural condition for the biosynthesis of extracellular alkaline protease from Streptomyces ambofaciens in free and immobilized form to obtain higher yield of this enzyme.

\section{MATERIALS AND METHODS}

\subsection{Microorganism and Culture Conditions}

Streptomyces ambofaciens NRRL 2420 used in this study was obtained from_Agricultural Research Service (ARS) Culture Collection (NRRL), USDA, Peoria, IL. The microorganism was maintained at $30^{\circ} \mathrm{C}$ on ISP-2 agar slants made up of malt extract $(1.0 \%)$, yeast extract $(0.4 \%)$, glucose $(0.4 \%)$, agaragar (2.0\%) (Pridham et al., 2002).

\subsubsection{Inoculum Preparation}

The inoculum was prepared by transferring a loop full of slant culture into $50 \mathrm{~mL}$ of sterile broth containing (g/L): Glucose 4 , yeast extract 4 and malt extract 10 $\mathrm{MgSO}_{4}, 7 \mathrm{H}_{2} \mathrm{O}$ 0.5. $\mathrm{pH}$ was adjusted to 7 . The inoculum was incubated at $30^{\circ} \mathrm{C}$ on a rotary shaker $(200 \mathrm{rpm})$ for $48 \mathrm{~h}$.

\subsubsection{Fermentation Protocol}

The initial fermentation medium composed of $(\mathrm{g} / \mathrm{L})$ : Glucose 10, yeast extract $5, \mathrm{~K}_{2} \mathrm{HPO}_{4} 0.5$ and $\mathrm{MgSO}_{4}$, $7 \mathrm{H}_{2} \mathrm{O} 0.5$ and $\mathrm{pH}$ 7. Media were autoclaved at $121^{\circ} \mathrm{C}$ for $20 \mathrm{~min}$. Inoculation of $2 \mathrm{~mL}$ vegetative growth was carried out in $250 \mathrm{~mL}$ Erlenmeyer flasks containing 50 $\mathrm{mL}$ of the fermentation medium followed by the estimation of protease activity.

\subsection{Analytical Methods}

Alkaline protease activity of culture filtrate was determined by calorimetric method (Hagihara, 1958) using casein as the substrate. $0.5 \mathrm{~mL}$ enzyme solution was added to $3.0 \mathrm{~mL}$ casein solution $(0.6 \% \mathrm{w} / \mathrm{v}$ casein solution prepared in $20 \mathrm{mM}$ Borax- $\mathrm{NaOH}$ buffer, $(\mathrm{pH} 10)$ and allowed to react for $10 \mathrm{~min}$ at $37^{\circ} \mathrm{C}$. The reaction was terminated by the addition of $3.2 \mathrm{~mL}$ stopper solution TCA mixture $(0.11 \mathrm{M}$ TCA, $0.22 \mathrm{M}$ sodium acetate, $0.33 \mathrm{M}$ acetic acid). The reaction mixture was then kept for 10 min the absorbance was measured at 280 $\mathrm{nm}$ and related to the protease activity.

\subsection{Optimization of Different Growth Conditions}

The effect of $\mathrm{pH}$ on alkaline protease production was determined by adjusting $\mathrm{pH}$ of the basal media ranging from 7-11. Optimum inoculum size was studied by incubating the medium with inoculum ranging from 1-5 percent. Influence of temperature on protease production was determined by incubating the culture media at temperatures ranging from $30-40^{\circ} \mathrm{C}$. After the incubation, the culture was filtered to separate the clear supernatant. The supernatant was analyzed for protease activity.

\subsection{Effect of Different Carbon Sources on Alkaline Protease Production}

Glucose was substituted with $(0.3 \%$ w/v $)$ starch, sucrose, mannose, maltose and lactose. All carbon sources were autoclaved separately. After sterilization of media, sugars were added separately and the microorganism was inoculated and incubated for $144 \mathrm{~h}$ at $30^{\circ} \mathrm{C}$ and $200 \mathrm{rpm}$.

\subsection{Immobilization and Cultivation of Streptomyces ambofaciens NRRL 2420}

Synthetic cotton fiber as adsorbent was cut into small parts about $0.5 \mathrm{~g} /$ flask and washed several times with distilled water before use. Three $\mathrm{ml}$ of 48 hours vegetative growth were inoculated into each Erlenmeyer flasks $(250 \mathrm{~mL})$. Each flask contained $50 \mathrm{~mL}$ of sterilized medium. Flasks were inoculated and incubated in an incubator shaker at $200 \mathrm{rpm}$ and $30^{\circ} \mathrm{C}$.

\subsection{Production of Alkaline Protease by Repeated Batch Process}

The reusability of Streptomyces ambofaciens cells immobilized on synthetic cotton fiber was examined. After attaining the maximum production of alkaline protease, the spent medium was replaced with fresh production medium $(50 \mathrm{~mL})$ and the process was repeated for several batches until the enzyme titers were not detected. All experiments were carried out in duplicate and average values were reported.

\subsection{Statistical Analysis}

The data in experiments were analysed using Analysis of Variance (ANOVA) from Minitab 16 software with $95 \%$ confidence interval to investigate if there is a statistically significant difference in the data recorded since it is necessary to determine if real difference exists between the means of the values. 


\section{RESULTS}

\subsection{Culture Conditions for Alkaline Protease Production}

\subsubsection{Effect of Initial pH of Fermentation Medium}

Different $\mathrm{pH}, 6.5,7,7.5,8,8.5,9,10$ and 11 were adjusted in the cultural media for fermentation process. The production increased gradually by increasing the initial $\mathrm{pH}$ till reaching the optimum $\mathrm{pH} 8.5$ at which highest protease activity was achieved (Fig. 1). Further increase in $\mathrm{pH}$ reduced enzyme production significantly. The effect of initial $\mathrm{pH}$ was significant on alkaline protease production $(\mathrm{p}<0.05)$ indicate that the factor level observations means are different.

The individual $95 \%$ confidence intervals provide one-sample $t$ intervals that estimate the mean response for each group level.

\begin{tabular}{|c|c|c|c|c|c|}
\hline \multicolumn{6}{|c|}{ One-way ANOVA: Protease activity $(\mathrm{U} / \mathrm{mL})$ versus pH } \\
\hline Source & DF & SS & MS & $\mathrm{F}$ & $\mathrm{P}$ \\
\hline $\mathrm{pH}$ & 7 & 9767.044 & 1395.292 & 3630.03 & 0.000 \\
\hline Error & 8 & 3.075 & 0.384 & & \\
\hline Total & 15 & 9770.119 & & & \\
\hline$S=0.6200$ & & $\mathrm{R}-\mathrm{Sq}=99$ & & $\mathrm{R}-\mathrm{Sq}(\mathrm{ad}$ & $=99.94 \%$ \\
\hline
\end{tabular}

DF: Degree of Freedom; SS: Sum Square; MS: Mean Square; F: F-test; P: Probability test

Individual 95\% CIs for Mean Based on Pooled StDev

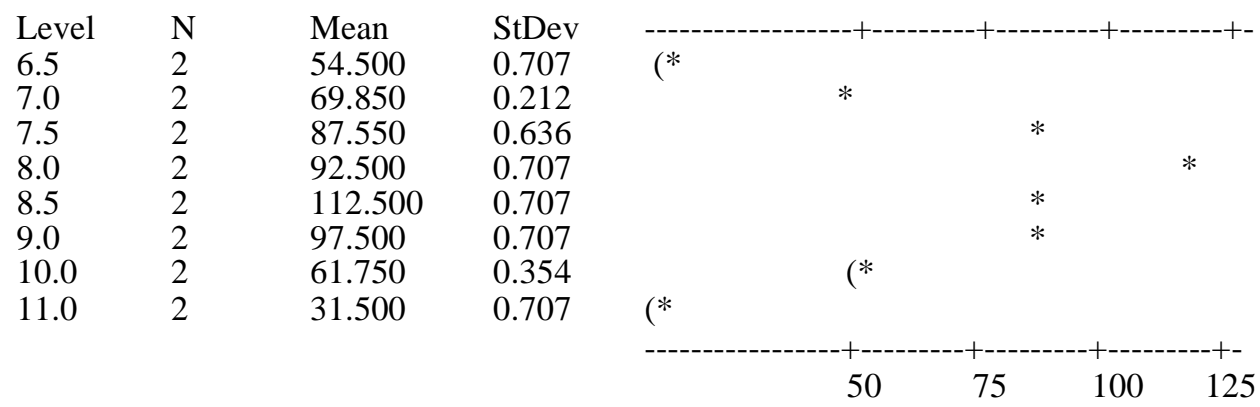

Pooled StDev $=0.620 ; \mathrm{N}$ : The number of observations for the level; StDev: Standard Deviation The * indicates the sample mean value

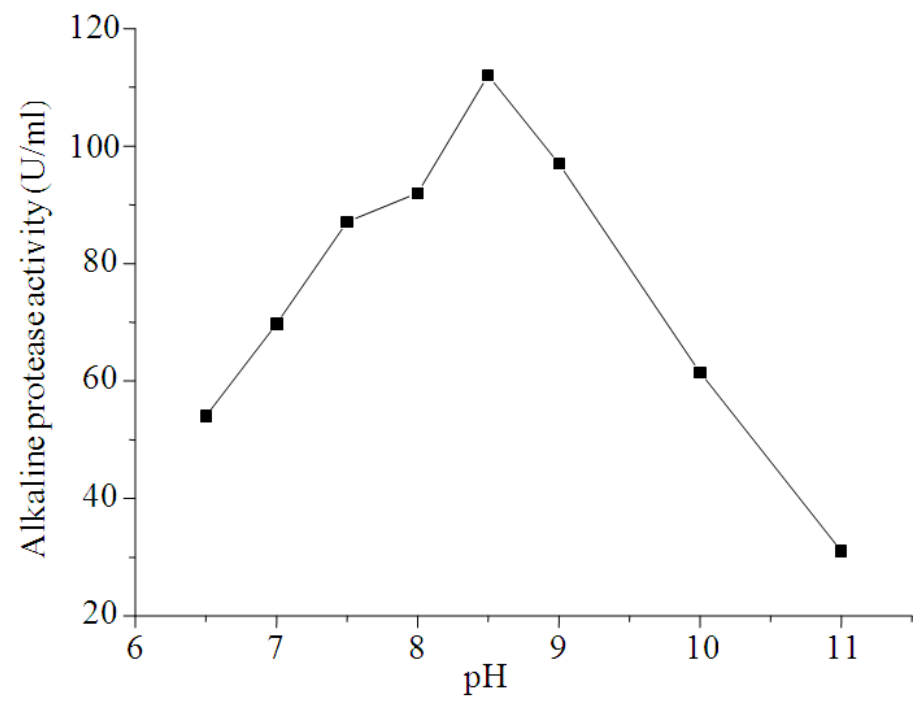

Fig. 1. Effect of different $\mathrm{pH}$ on alkaline protease activity 
The interval plot shows that $\mathrm{pH} 6.5 ; 8.5$ and 11 groups are definitely different in means as their intervals do not overlap. It can be concluded that the difference between the means are significant at confidence intervals $95 \%$.

\subsubsection{Effect of Different Incubation Time}

Protease activity was detected only after $24 \mathrm{~h}$ of incubation period recorded a weak activity of (16.6 U
$\left.\mathrm{mL}^{-1}\right)$. Production was increased gradually by time till reached its maximum value of $\left(112 \mathrm{U} \mathrm{mL}^{-1}\right)$ at the fourth day of the fermentation process followed by gradual decrease in activity by the 6 th day reaching 31 $\mathrm{U} \mathrm{mL}^{-1}$. At the 7 th day no activity was detected (Fig. 2). The effect of incubation time was significant on alkaline protease production since $(\mathrm{p}<0.05)$.

$\begin{array}{llllll}\text { One-way ANOVA: } & \text { Protease activity }(\mathbf{U} / \mathbf{m L}) & \text { versus } & \text { incubation time } & & \\ \text { Source } & \mathrm{DF} & \mathrm{SS} & \mathrm{MS} & \mathrm{F} & \mathrm{P} \\ \text { Incubation time } & 6 & 30588 & 5098 & 28.09 & 0.000 \\ \text { Error } & 14 & 2541 & 181 & & \\ \text { Total } & 20 & 33128 & & & \end{array}$

$\mathrm{S}=13.47 \quad \mathrm{R}-\mathrm{Sq}=92.33 \% \quad \mathrm{R}-\mathrm{Sq}(\mathrm{adj})=89.04 \%$

\begin{tabular}{|c|c|c|c|c|}
\hline Level & $\mathrm{N}$ & Mean & StDev & Individual $95 \%$ CIs for mean based on \\
\hline 24 & 3 & 8.10 & 1.01 & $\left(---*_{---}\right)$ \\
\hline 48 & 3 & 16.20 & 1.06 & $(---*---)$ \\
\hline 72 & 3 & 81.00 & 1.00 & $\left(---*_{---}\right)$ \\
\hline 96 & 3 & 111.67 & 1.53 & $\left(---*_{---}\right)$ \\
\hline 120 & 3 & 57.00 & 35.51 & $\left(---*_{---}\right)$ \\
\hline 144 & 3 & 31.00 & 1.00 & $\left(---*_{---}\right)$ \\
\hline \multirow[t]{3}{*}{168} & 3 & 1.00 & 1.73 & $(---*---)$ \\
\hline & & & & ----+----------+----------+----------+----- \\
\hline & & & & 120 \\
\hline
\end{tabular}

Pooled StDev $=13.47$

$\mathrm{N}$ : The number of observations for the level; StDev: Standard deviation

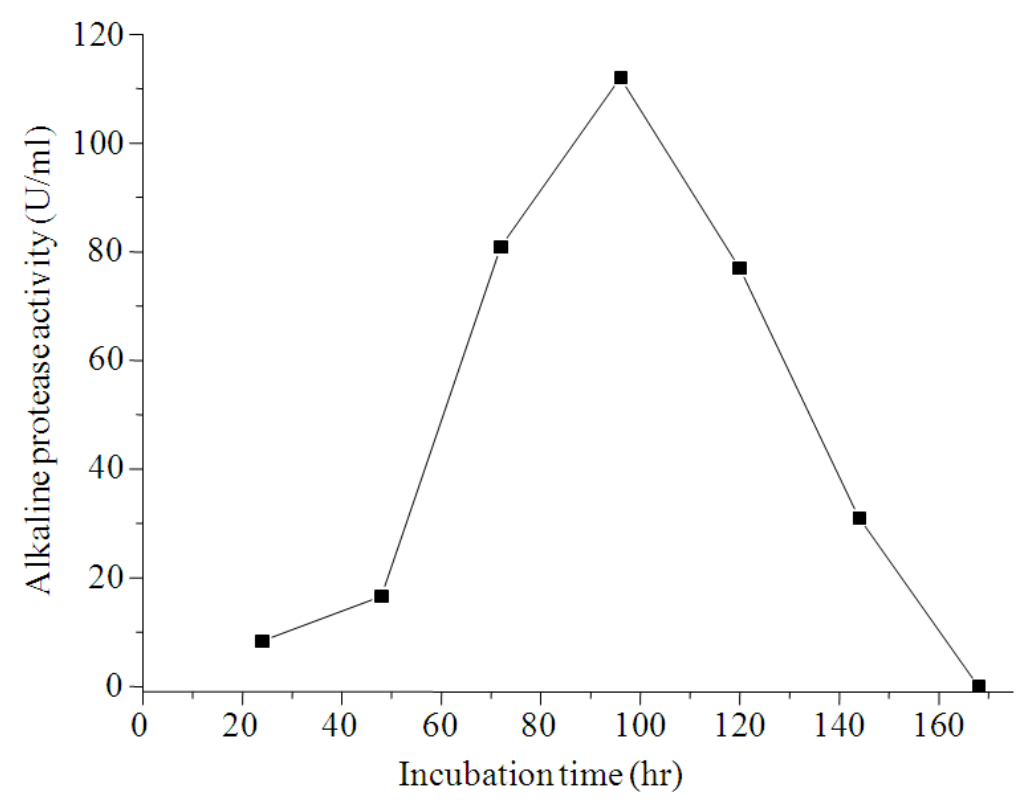

Fig. 2. Effect of different incubation time on alkaline protease activity 
The interval plot shows that incubation time $24 ; 72$ and 96 groups are definitely different in means. Their intervals do not overlap. It can be concluded that the difference between the means are significant at confidence intervals $95 \%$.

\subsubsection{Effect of Different Medium Volume}

The highest productivity was attained at medium volume of $50 \mathrm{~mL} /$ flask yielded $112 \mathrm{U} \mathrm{mL}^{-1}$ furthermore, a decrease in the enzyme level have been observed with the increase in medium volume (Fig. 3), then the yield decreased by increasing the volume of the fermentation medium till reaching $100 \mathrm{~mL} /$ flask only $24.39 \mathrm{U} \mathrm{mL}^{-1}$ was detected. The effect of medium volume was significant on alkaline protease production $(\mathrm{p}<0.05)$.

The interval plot shows that medium volume $25 ; 50$; 75 and 100 groups are definitely different in means. Their intervals do not overlap. It can be concluded that the difference between the means are significant at confidence intervals $95 \%$.

\begin{tabular}{llllll}
\multicolumn{2}{l}{ One-way ANOVA: } & \multicolumn{7}{c}{ Protease activity(u/ml) } & versus medium volume(ml/flask) & & \\
Source & DF & SS & MS & F & P \\
medium volume(ml/flask) & 3 & 9938.32 & 3312.77 & 2140.85 & 0.000 \\
Error & 4 & 6.19 & 1.55 & & \\
Total & 7 & 9944.51 & & &
\end{tabular}

$\mathrm{S}=1.244 \quad \mathrm{R}-\mathrm{Sq}=99.94 \% \quad \mathrm{R}-\mathrm{Sq}(\mathrm{adj})=99.89 \%$

$\begin{array}{clll}\text { Level } & \mathrm{N} & \text { Mean } & \text { StDev } \\ 25 & 2 & 96.12 & 1.24 \\ 50 & 2 & 113.00 & 1.41 \\ 75 & 2 & 49.18 & 1.16 \\ 100 & 2 & 25.20 & 1.14\end{array}$

Individual 95\% CIs For Mean Based on Pooled StDev

(*)

$(*)$

$(*)$

(*)

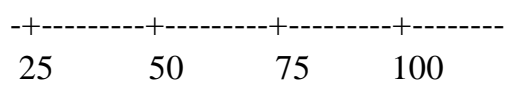

Pooled StDev $=1.24$

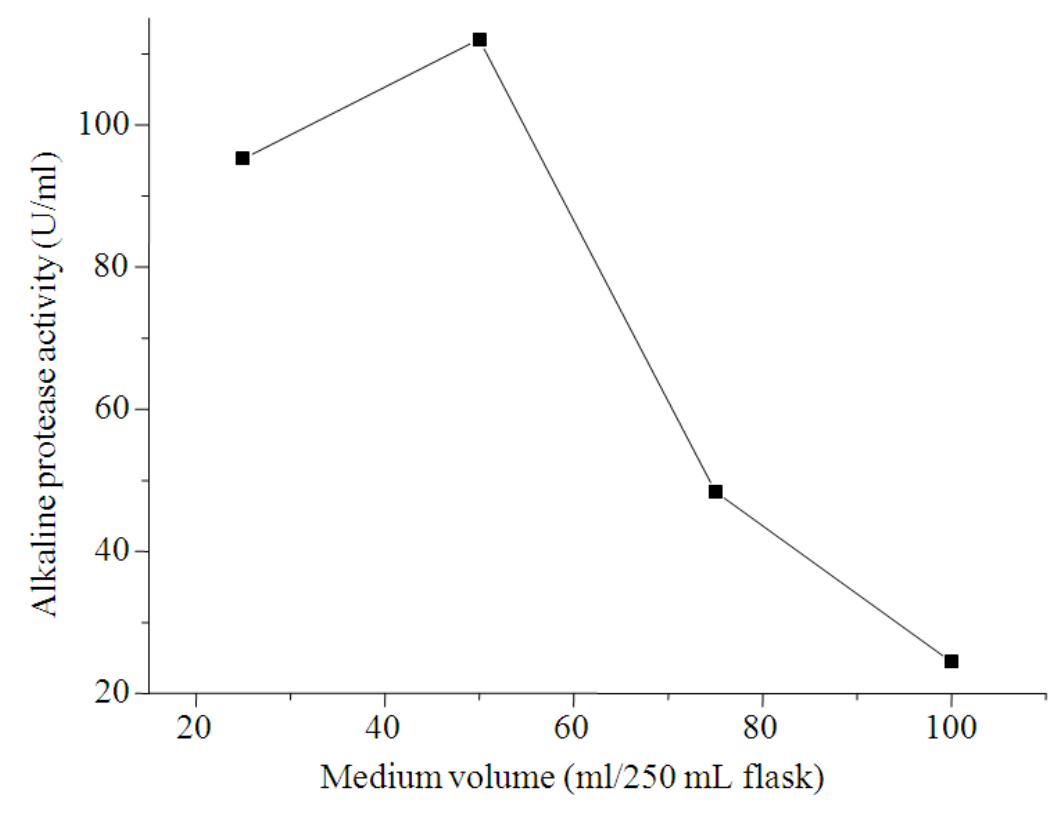

Fig. 3. Effect of different medium volume on alkaline protease activity 


\subsubsection{Effect of Different Temperature}

Temperature is one of the critical parameters that has to be optimized. The optimum temperature for alkaline protease production was found to be $30^{\circ} \mathrm{C}$. Considerable enzyme production was observed between 30-35 (Fig. 4). The effect of temperature was significant on enzyme production $(\mathrm{p}<0.05)$.

One-way ANOVA: Protease activity $(\mathrm{u} / \mathrm{mL})$ versus temperature

$\begin{array}{llllll}\text { Source } & \text { DF } & \text { SS } & \text { MS } & \text { F } & \text { P } \\ \text { Temperature } & 5 & 18825.61 & 3765.12 & 3924.15 & 0.000 \\ \text { Error } & 6 & 5.76 & 0.96 & & \\ \text { Total } & 11 & 18831.36 & & & \end{array}$

$\mathrm{S}=0.9795 \quad \mathrm{R}-\mathrm{Sq}=99.97 \% \quad \mathrm{R}-\mathrm{Sq}(\operatorname{adj})=99.94 \%$

$\begin{array}{llll}\text { Level } & \mathrm{N} & \text { Mean } & \text { StDev } \\ 25 & 2 & 39.515 & 0.728 \\ 30 & 2 & 111.500 & 0.707 \\ 35 & 2 & 107.900 & 1.273 \\ 40 & 2 & 67.860 & 1.216 \\ 45 & 2 & 34.900 & 1.273 \\ 50 & 2 & 2.060 & 0.085\end{array}$

Individual 95\% CIs For Mean Based on Pooled StDev

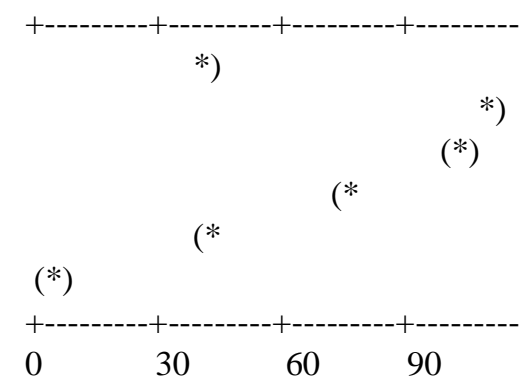

Pooled StDev $=0.980$

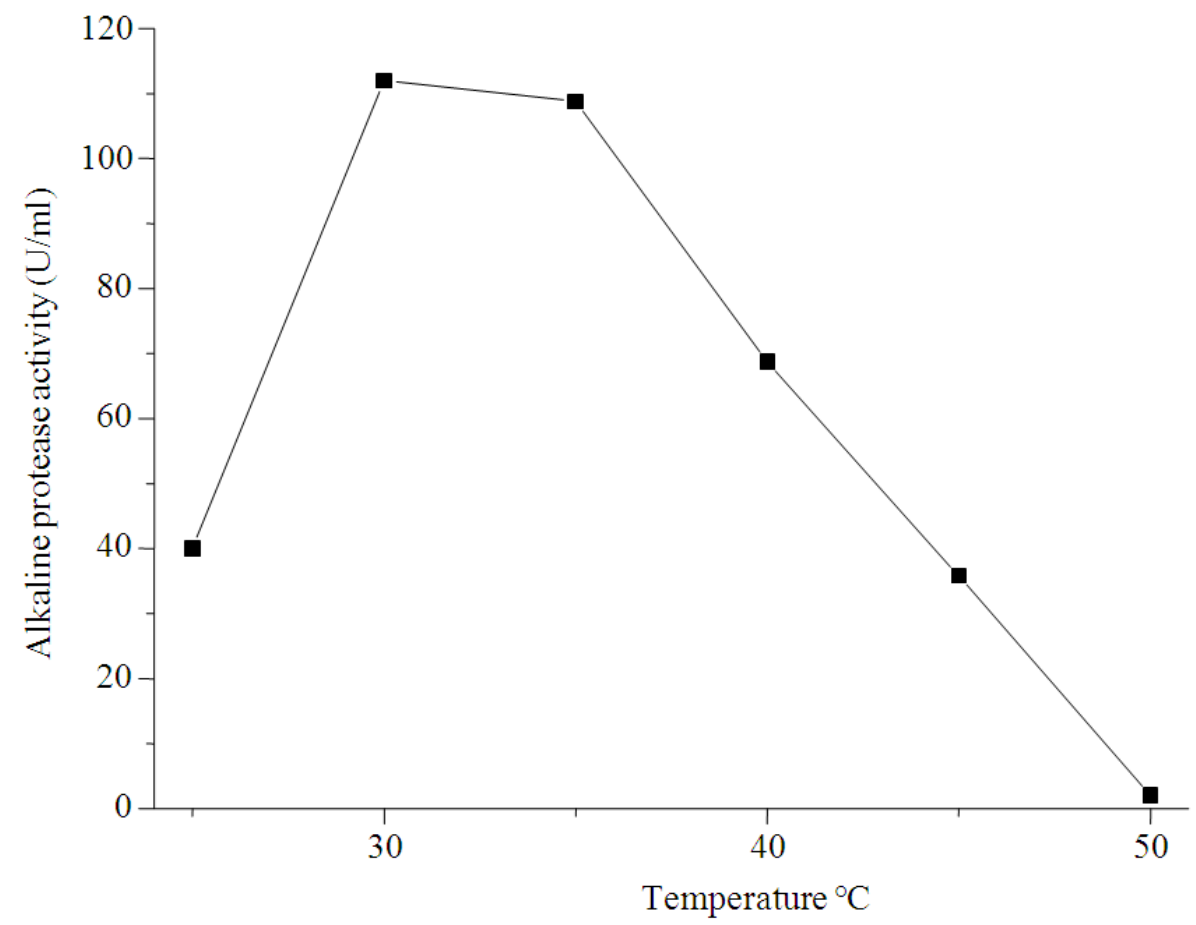

Fig. 4. Effect of different temperature on alkaline protease activity 


\subsubsection{Effect of Different Carbon Sources}

The basal production medium for protease production possesses glucose as carbon source. When glucose was replaced by various sugars, starch, sucrose, fructose, maltose, lactose and galactose. Starch was found to be the most effective carbon source for protease production compared with the others (Fig. 5). The effect of carbon sources was significant on the production $(\mathrm{p}<0.05)$. When starch concentrations increased from 5 to $20 \mathrm{~g}$ $\mathrm{L}^{-1}$, an approximately linear relationship between alkaline protease yielding and the starch concentration was observed until maximum protease production were attained (342.18 unit $\mathrm{mL}^{-1}$ ) at $20 \mathrm{~g} \mathrm{~L}^{-1}$ starch as listed in Table 1. However, increasing starch concentrations above $20 \mathrm{~g} \mathrm{~L}^{-1}$ was concomitant with decreased alkaline protease yield.

The interval plot shows that carbon sources lactose and maltose are definitely equal in means hence the difference between the means are not significant for production at confidence intervals $95 \%$.

\begin{tabular}{lcll}
\multicolumn{5}{l}{ One-way } & ANOVA: Protease activity versus carbon sources \\
Source & DF & SS & MS \\
C.S & 6 & 39530.49 & 6588.42 \\
Error & 7 & 1.73 & 0.25 \\
Total & 13 & 39532.22 & \\
S $=0.4967$ & $\mathrm{R}-S q=100.00 \%$ & R-Sq $(\mathrm{adj})=99.99 \%$ \\
\multicolumn{1}{l}{ Level } & $\mathrm{N}$ & Mean & StDev \\
1 & 2 & 193.625 & 0.530 \\
2 & 2 & 132.940 & 0.085 \\
3 & 2 & 112.500 & 0.707 \\
4 & 2 & 100.640 & 0.509 \\
5 & 2 & 69.588 & 0.583 \\
6 & 2 & 69.588 & 0.583 \\
7 & 2 & 10.990 & 0.014
\end{tabular}

Pooled StDev $=0.497$

$\begin{array}{ll}\text { F } & \text { P } \\ 26707.33 & 0.000\end{array}$

Individual 95\% CIs for Mean Based on Pooled StDev

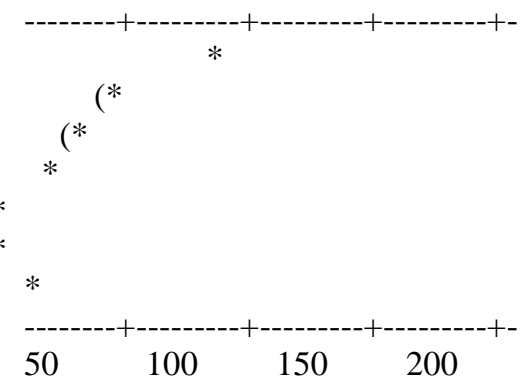

1: Starch; 2: Sucrose; 3: Glucose; 4: Fructose; 5: Lactose; 6: Maltose; 7: Galactose

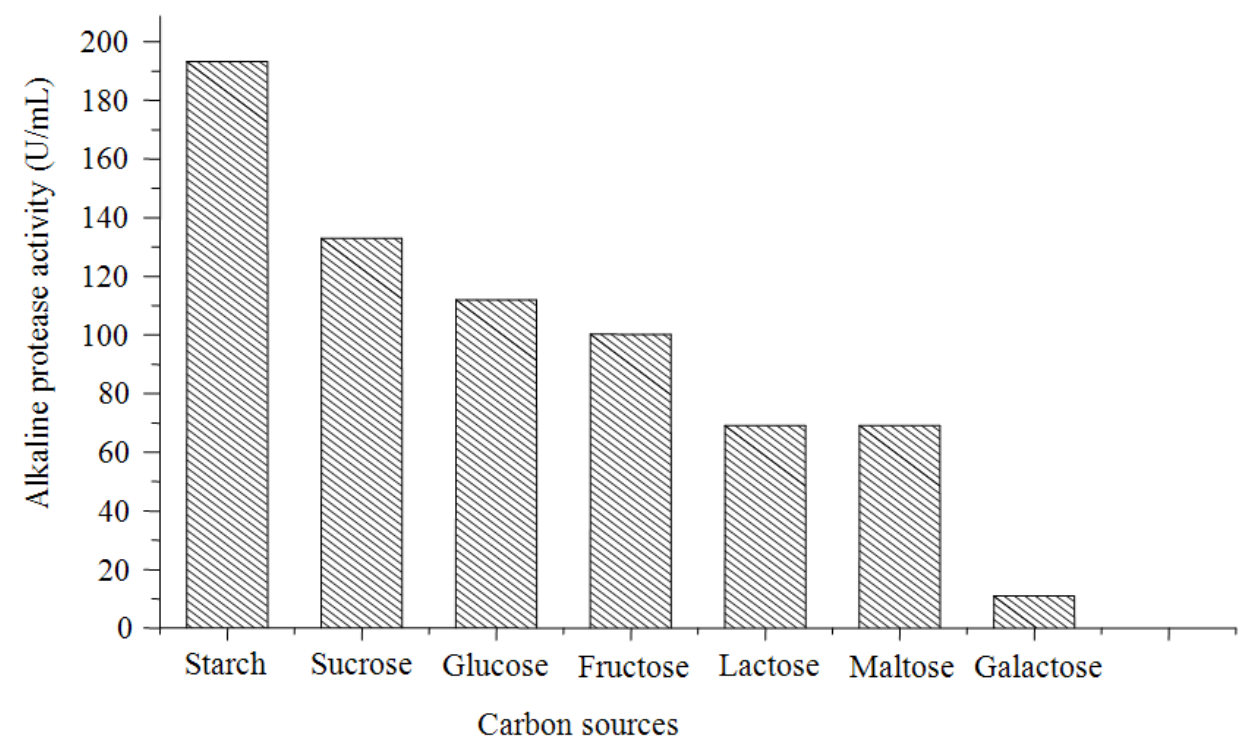

Fig. 5. Effect of different carbon sources on alkaline protease activity 


\begin{tabular}{|c|c|c|c|c|c|}
\hline \multicolumn{6}{|c|}{ One-way ANOVA: Protease activity (U/mL) versus Starch concentration (g/L) } \\
\hline Source & DF & SS & MS & $\mathrm{F}$ & $\mathrm{P}$ \\
\hline Starch concentration $(\mathrm{g} /$ & 5 & 139846.1 & 27969.2 & 34458.99 & 0.000 \\
\hline Error & 6 & 4.9 & 0.8 & & \\
\hline Total & 11 & 139850.9 & & & \\
\hline
\end{tabular}

$\mathrm{S}=0.9009 \quad \mathrm{R}-\mathrm{Sq}=100.00 \% \quad \mathrm{R}-\mathrm{Sq}(\operatorname{adj})=99.99 \%$

$\begin{array}{clll}\text { Level } & \mathrm{N} & \text { Mean } & \text { StDev } \\ 5 & 2 & 35.900 & 0.141 \\ 10 & 2 & 193.500 & 0.707 \\ 15 & 2 & 259.130 & 1.230 \\ 20 & 2 & 342.590 & 0.580 \\ 25 & 2 & 331.000 & 1.414 \\ 30 & 2 & 325.500 & 0.707\end{array}$

Individual 95\% CIs for Mean Based on Pooled StDev

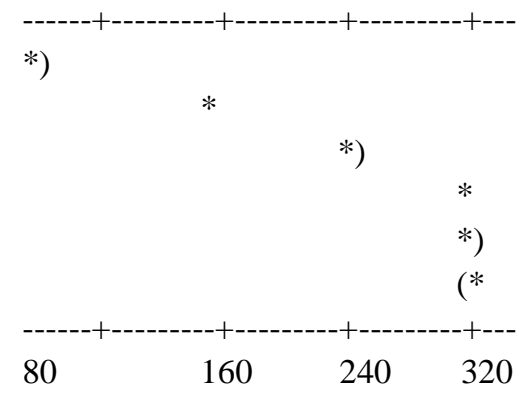

Pooled StDev $=0.901$

The interval plot shows that starch concentration at 5; $10 ; 15$ are 20 are definitely different in means hence the difference between the means are significant for production at confidence intervals $95 \%$.

\subsubsection{Effect of Different Nitrogen Sources}

Yeast extract was replaced by various organic and inorganic nitrogen sources in the production medium. Among the inorganic nitrogen sources, ammonium sulphate was found to be better among them for the production of the enzymes. However, among the organic nitrogen sources tested, yeast extract exhibited a prominent effect on the yield of protease, while peptone gave lower yield of protease. Casein cause a decrease in enzyme yield (Table 2). It was observed that the effect of nitrogen sources was significant on alkaline protease production $(\mathrm{p}<0.05)$.

$\begin{array}{llllll}\text { One-way ANOVA: Protease activity } & (\mathbf{U} / \mathbf{m L}) & \text { versus nitrogen sources } & & \\ \text { Source } & \mathrm{DF} & \mathrm{SS} & \mathrm{MS} & \mathrm{F} & \mathrm{P} \\ \text { Different nitrogen source } & 6 & 108026.7 & 18004.5 & 148499.10 & 0.000 \\ \text { Error } & 7 & 0.8 & 0.1 & & \\ \text { Total } & 13 & 108027.6 & & \end{array}$

$\mathrm{S}=0.3482 \quad \mathrm{R}-\mathrm{Sq}=100.00 \% \quad \mathrm{R}-\mathrm{Sq}(\operatorname{adj})=100.00 \%$

$\begin{array}{llll}\text { Level } & \text { N } & \text { Mean } & \text { StDev } \\ \text { Ammonium nitrate } & 2 & 93.770 & 0.325 \\ \text { Ammonium sulphate } & 2 & 140.900 & 0.141 \\ \text { Casein } & 2 & 75.970 & 0.042 \\ \text { Peptone } & 2 & 92.845 & 0.219 \\ \text { Potassium nitrate } & 2 & 95.620 & 0.537 \\ \text { Sodium nitrate } & 2 & 85.845 & 0.219 \\ \text { Yeast extract } & 2 & 342.590 & 0.580\end{array}$

Pooled StDev $=0.348$

Individual 95\% CIs for Mean Based on Pooled StDev

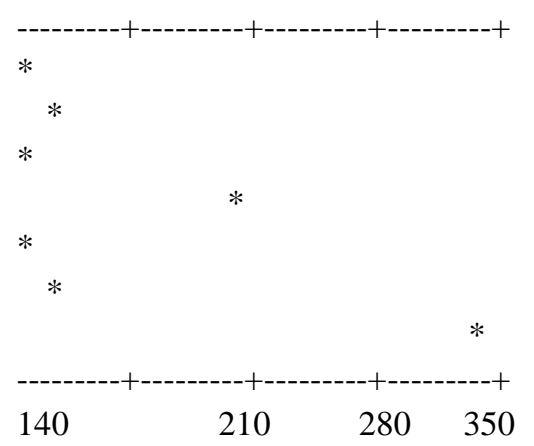


The highest yield was noticed with $5 \mathrm{~g} \mathrm{~L}^{-1}$ yeast extract when used as the sole nitrogen source in the presence of $20 \mathrm{~g} \mathrm{~L}^{-1}$ starch instead of glucose. At higher concentrations, the enzyme secretion was repressed (Fig. 6). It was observed that the effect yeast extract was significant on alkaline protease production $(\mathrm{p}<0.05)$. However, there is no report on the nitrogen repression of alkaline protease from actinomycetes. After optimization of the cultural composition of the production medium for the biosynthesis of extracellular alkaline protease by Streptomyces ambofaciens NRRL 2420, the results indicated that the cultural filtrate possessed about $342 \mathrm{U}$ $\mathrm{mL}^{-1}$. This medium composition was therefore used in all succeeding work.

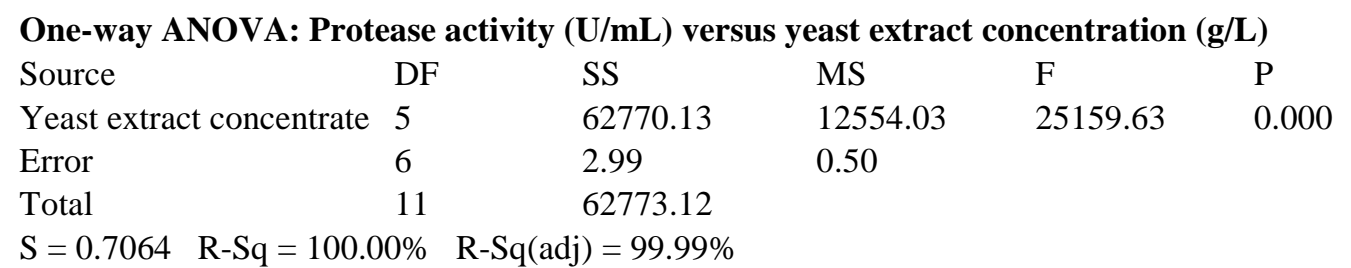

$\mathrm{S}=0.7064 \quad \mathrm{R}-\mathrm{Sq}=100.00 \% \quad \mathrm{R}-\mathrm{Sq}(\mathrm{adj})=99.99 \%$

$\begin{array}{llll}\text { Level } & \mathrm{N} & \text { Mean } & \text { StDev } \\ 2.5 & 2 & 193.500 & 0.707 \\ 5.0 & 2 & 342.590 & 0.580 \\ 6.0 & 2 & 258.630 & 0.523 \\ 7.0 & 2 & 251.630 & 0.523 \\ 8.0 & 2 & 179.255 & 1.054 \\ 9.0 & 2 & 112.500 & 0.707\end{array}$

Individual 95\% CIs for Mean Based on Pooled StDev

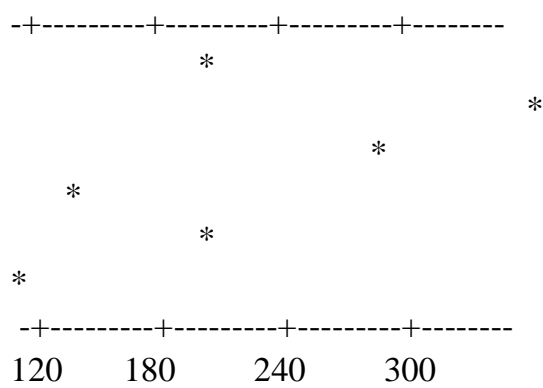

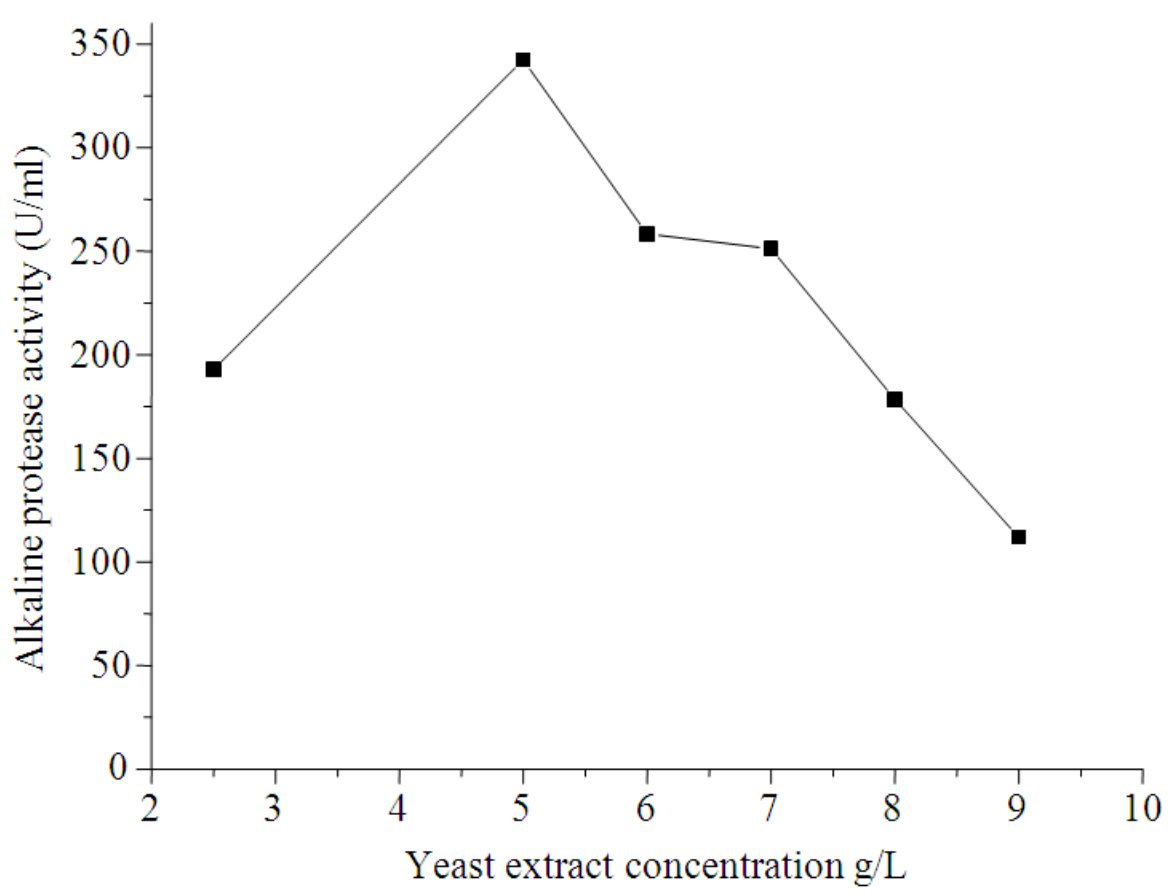

Fig. 6. Effect of different yeast extract concentration on alkaline protease production 
Nayera A.M. Abdelwahed et al. / American Journal of Biochemistry and Biotechnology 10 (1): 1-13, 2014

Mean Plot of multiple variables grouped by incubation time (hr)

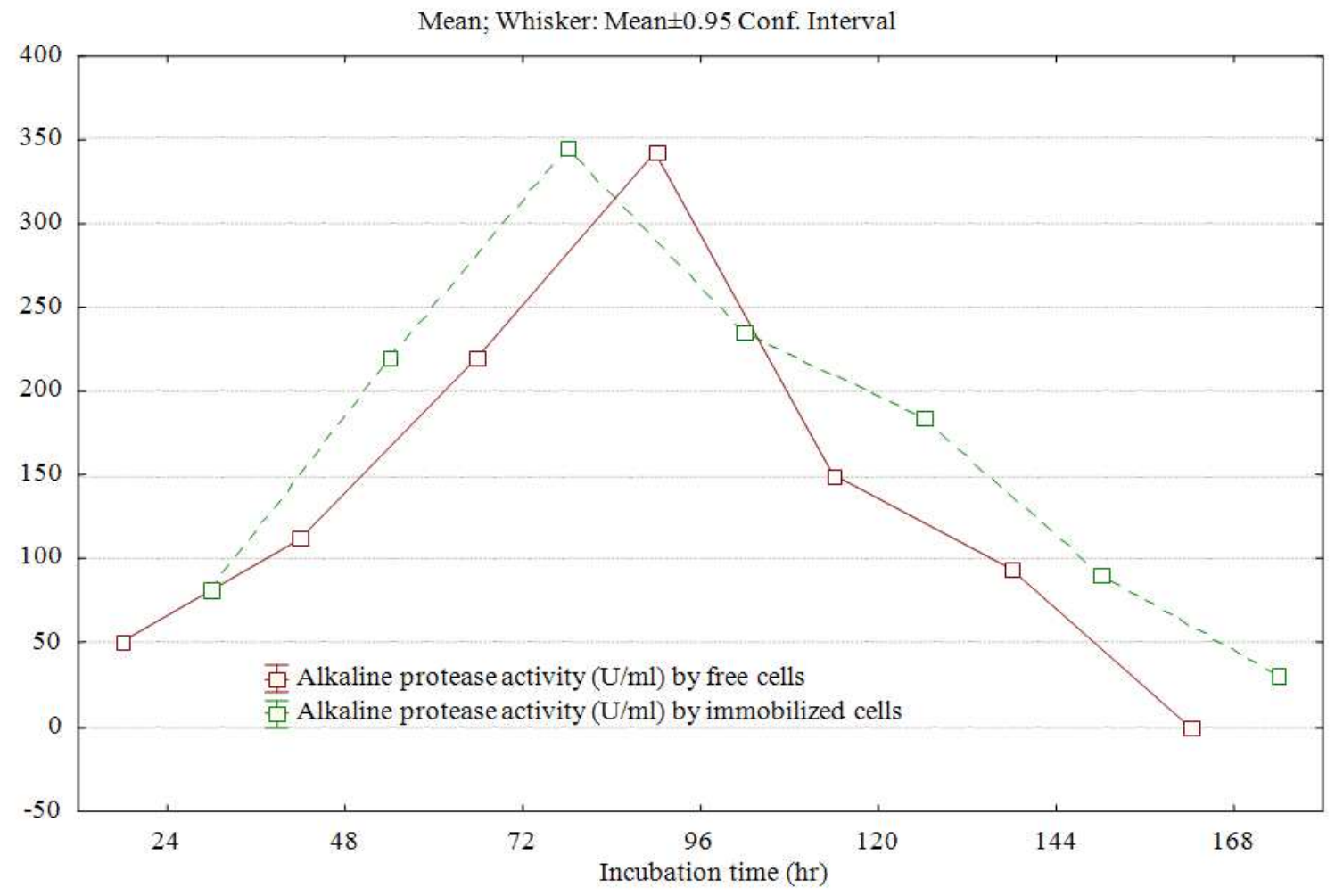

Fig. 7. Comparison between the production of alkaline protease by Streptomyces ambofaciens NRRL 2420 in free and immobilized form. Empty objects depict the mean and whiskers 0.95 the confidence interval

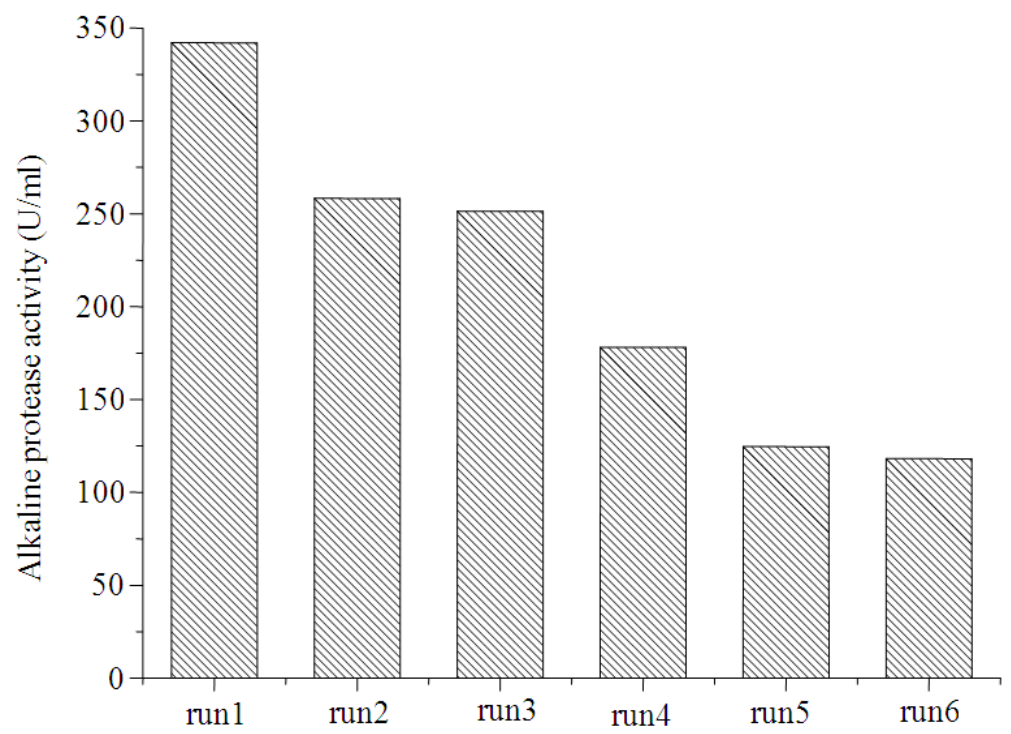

Fig. 8. Repeated batch cultivation using immobilized cells of Streptomyces ambofaciens NRRL 2420 
Table 1. Effect of different starch concentration on alkaline protease production

\begin{tabular}{lc}
\hline $\begin{array}{l}\text { Starch } \\
\text { concentration }(\mathrm{g} / \mathrm{L})\end{array}$ & $\begin{array}{l}\text { Alkaline protease } \\
\text { activity } \mathrm{U} / \mathrm{mL})\end{array}$ \\
\hline 5 & 35.80 \\
10 & 193.00 \\
15 & 258.26 \\
20 & 342.18 \\
25 & 330.00 \\
30 & 325.00 \\
\hline
\end{tabular}

Table 2. Effect of different nitrogen sources

\begin{tabular}{lc}
\hline $\begin{array}{l}\text { Different } \\
\text { nitrogen sources }\end{array}$ & $\begin{array}{c}\text { Alkaline protease } \\
\text { activity }(\mathrm{U} / \mathrm{mL})\end{array}$ \\
\hline Yeast extract & 342.18 \\
Ammonium sulphate & 140.80 \\
Potassium nitrate & 95.24 \\
Ammonium nitrate & 93.54 \\
Peptone & 92.69 \\
Sodium nitrate & 85.69 \\
Casein & 75.94 \\
\hline
\end{tabular}

The interval plot shows that yeast extract concentration at $6 \mathrm{~g} \mathrm{~L}^{-1}$ and $7 \mathrm{~g} \mathrm{~L}^{-1}$ are definitely equal in means hence the difference between the means are not significant for production at confidence intervals $95 \%$. Immobilization of Streptomyces ambofaciens NRRL 2420 by adsorption on synthetic cotton fiber was investigated under the optimized conditions for alkaline protease production by free cells. The analysis of enzyme production was carried out at $24 \mathrm{~h}$ intervals. In case of free cells, enzyme production reached a maximum activity of $342 \mu \mathrm{mL}^{-1}$ at $96 \mathrm{~h}$ of incubation. On further incubation, the enzyme activity gradually decreased. However, the cells immobilized on synthetic cotton fiber showed a significant increase in the production from the beginning of the cultivation process. Maximum enzyme titer (344 $\mu$ $\mathrm{mL}^{-1}$ ) was observed at $72 \mathrm{~h}$ of incubation. STATISTICA sigma software (Version 8.0, StatSoft Inc., USA) was used to plot the graph of Fig. 7. The enzyme production by immobilized cells reached approximately $220 \mu \mathrm{mL}^{-1}$ at $48 \mathrm{~h}$, which could only be obtained after $72 \mathrm{~h}$ with free cells. From the results obtained, it is evident that the production of alkaline protease by immobilized cells is higher than that of free cells. The possible reuse of Streptomyces ambofaciens NRRL 2420 onto synthetic cotton fiber for alkaline protease production in the semicontinuous mode was carried out by replacement of the cultural medium by a fresh one under aseptic condition each 3 days over a period of 15 days (Fig. 8). The highest enzyme activity of $342.18 \mu \mathrm{mL}^{-1}$ and $258.26 \mu$ $\mathrm{mL}^{-1}$ were recorded in the first and second runs. Further replacement of the medium had no positive effect on enzyme productivity which remained between 251.26 $124.66 \mu \mathrm{mL}^{-1}$ throughout the third and fourth cycles followed by a decrease in the enzyme activity until the fifth run reached $118.1 \mu \mathrm{mL}^{-1}$.

\section{DISCUSSION}

Media $\mathrm{pH}$ plays an important role in the activity of enzymes. The present protease exhibited great activity in the $\mathrm{pH}$ 8.5. It has been reported that a $\mathrm{pH}$ of 9.0 to be optimum for alkaline protease production by Streptomyces pulvereceus MTCC 8374 (Jayasree et al., 2009). These results were synonymous to that have been investigated by (Nadeem et al., 2008). The results of the effect of incubation time confirmed the observation of which reported that an increase of protease production by Streptomyces cyanens and S. rimosus during log phase (Petinate et al., 1999; Yang and Wang, 1999). This indicates that high level of protease production is observed during active biomass production. Based on the results of the previous studies, high concentrations of oxygen had a stimulatory effect on microbial growth and enzyme production (Yegneswaran and Gray, 1991). Temperature is an important environmental factor for growth and enzyme production. The obtained result was in agreement with previous reports for protease production from streptomycetes (Chaphalkar and Deys, 1998; Kim and Lee, 1995; Yeoman and Edwards, 1994). Increasing of the alkaline protease was reported by several workers using different sugars such as fructose (Sen and Satyanarayana, 1993) and lactose (Malathi and Chakraborty, 1991). Reports concluded that yeast extract excited the biosynthesis of protease from streptomyces species (Laluce and Molinari, 1977; Yang and Lee, 2001). The use of inorganic nitrogen sources supported a moderate production of protease which matching the results obtained by some reports (Sinha and Satyanarayana, 1991; Chaphalkar and Deys, 1998). Although some carbon and nitrogen sources showed stimulatory effect on the microbial growth, they had an inhibitory effect on the biosynthesis of primary metabolites because of organic acid accumulation, oxygen depletion and glucose catabolic repression. Same phenomena were also found in protease production in Streptomyces rimosus (Yang and Lee, 2001). Cell immobilization is one of the common techniques for increasing the overall cell concentration and productivity. The separation of products from immobilized cells is easier compared to suspended cell systems (Beshay, 2003). The enzyme production profiles 
reveal a clear difference between the activities of free and immobilized cells in fermentation processes. The immobilized-cell system leads to higher enzyme activity than that of the free-cell system during the same period of fermentation. This may be due to the depletion of essential nutrients required for the growth of the microorganism free cells. Furthermore, the long term stability and reusability of the matrix also add to the specific advantages. The higher production in case of immobilized cells could be due to the minimal growth of cells in the matrix and also due to enzyme activities being retained at higher levels than that of the free cells (Kar and Ray, 2008). A $32 \%$ increase in pectinase production by Streptomyces sp. RCK-SC was reported after employing a polyurethane foam as an inert support matrix (Kuhad et al., 2004). Similarly, a 1.5 fold increase in polygalactouronase production by Bacillus sp. MGcp-2 using the polyurethane foam as support matrix (Kapoor et al., 2000).

\section{CONCLUSION}

This is the first report on alkaline protease production by (Streptomyces ambofaciens NRRL 2420). The optimized conditions of the fermentation media can be implemented in large scale for production of alkaline proteases.

\section{REFERENCES}

Amit, V., P.H. Singh, S. Rachna and A. Sanjeev, 2011. Potential of alkaline protease isolated from Thermoactinomyces sp. RM4 as an alternative to conventional chemicals in leather industry dehairing. Int. J. Agric. Environ. Biotech., 4: 173178 .

Banerjee, C.U., R.K. Sani and W. Azmi, 1999. Thermostable alkaline protease from Bacillus brives and its characterization as laundry additives. Proc. Biochem., 35: 213-219. DOI: 10.1016/S00329592(99)00053-9

Beshay, U., 2003. Production of alkaline protease by Teredinobacter turnirae cells immobilized in $\mathrm{Ca}-$ alginate beads. Afr. J. Biotechnol., 2: 60-65. DOI: $10.4314 \% 2$ Fajb.v2i3.14803

Chaphalkar, S.R. and Deys, 1998. Thermostable alkaline mettalloprotease from newly isolated alkaliphilic Streptomyces diastaticus Strain SSI. Indian J. Biochem. Biophys., 35: 34-40. PMID: 9699417
Giarrhizzo, J., J. Bubis and A. Taddei, 2007. Influence of the culture medium composition on the excreted/secreted proteases from Streptomyces violaceoruber. World J. Microbiol. Biotechnol., 23: 553-558. DOI: 10.1007/s11274-006-9260-Z

Gupta, R., Q.K. Beg and P. Lorenz, 2002. Bacterial alkaline proteases: Molecular approaches and industrial applications. Applied Microbiol. Biotechnol., 59: 15-32. DOI: 10.1007/s00253-0020975-y

Hagihara, B., 1958. The Enzymes. 4th Edn., Academic Press Inc., New York.

James, P.D.A., M. Iqbal, C. Edwards and P.G.G. Miller, 1991. Extracellular protease activity in antibiotic producing Streptomyces thermovioleceus. Curr. Microbiol., 22: 377-382.

Jayasree, D., T.D.S. Kumari, P.B.K. Kishor, M.V. Lakshmi and M.L. Narasu, 2009. Optimization of production protocol of alkaline protease by Streptomyces pulvereceus. Int. JRI Sci. Technol., 1: 79-82.

Kapoor, M., Q.K. Beg, B. Bushan, K.H. Dadhich and G.S. Hoondal, 2000. Production and partial purification and characterization of a thermoalkalistable polygalactouronase from Bacillus sp. Mgcp-2. Proc. Biochem., 36: 467-473. DOI: 10.1016/S0032-9592(00)00238-7

Kar, S. and R.C. Ray, 2008. Statistical optimization of Lamylase production by Streptomyces erumpens MTCC 7317 cells in calcium alginate beads using response surface methodology. Pol. J. Microbiol., 57: 49-57. PMID: 18610656

Kim, I. and K. Lee, 1995. Physiological roles of leupeptin and extracellular proteases in mycelium development of Streptomyces exfoliatus $\mathrm{SMF}_{13}$. Microbiology, 141: 1017-1025. DOI: 10.1099/13500872-141-4-1017

Kuhad, R.C., M. Kapoor and R. Rustagi, 2004. Enhanced production of an alkaline pectinase by Streptomyces sp. RCK-SC by whole cell immobilization and solid-state cultivation. World J. Microbiol. Biotechnol., 20: 257-263. DOI: 10.1023/B:WIBI.0000023833.15866.45

Laluce, C. and R. Molinari, 1977. Selection of a chemically defined medium for submerged cultivation of Streptomyces aureofaciens with high extracellular caseinolytic activity. Biotechnol. Bioeng., 19 : 1863-1884. DOI: 10.1002/bit.260191210 
Malathi, S. and R. Chakraborty, 1991. Production of alkaline protease by a new Aspergillus flavus isolate under solid substrate fermentation conditions for use as a depilation agent. Applied Environ. Microbiol., 57: 712-716. PMID: 16348437

Nadeem, M., J.I. Qazi, S. Baig and Q.A. Syed, 2008. Effect of medium composition on commercially important alkaline protease production by Bacillus licheniformis N-2. Food Technol. Biotechnol., 46: 388-394.

Ozawa, S., K. Amada, K. Sato, T. Kobayashi and T. Nagamune et al., 1992. Production of alkaline protease by the novel solid-state fermentation system using urethane foam as carriers. Proceedings of Asia-Pacific Biochemical Engineering Conference, (APBEC' 92), Springer-Verlag, Tokyo, pp: 405-408.

Ozawa, S., K. Sato and I. Endo, 1996. Repeated batch production of alkaline protease by solid-state fermentation using urethane foam as carriers. Bioprocess Eng., 14: 63-68. DOI: 10.1007/BF00387959

Petinate, D.G., R.M. Martins, R.R.R. Coelho, M.N.L Meirelles and M.H. Branquinha et al., 1999. Influence of growth medium in protease and pigment production by Streptomyces cyanens. Mem Inst. Oswaldo Cruz, Rio de Jenerio., 94: 173-177.

Phadatare, S.U., V.V. Deshpande and M.C. Srinivasan, 1993. High activity alkaline protease from Conidiobolus coronatus (NCL' 86.8.20): Enzyme production and compatibility with commercial detergents. Enzyme Microb. Technol., 15: 72-76. DOI: 10.1016/0141-0229(93)90119-M

Porto, A.L.F., G.M. Campos-Takaki and J.L. Lima Filho, 1996. Effects of culture conditions on protease production by Streptomyces clavuligerus growing on soy bean flour medium. Applied Biochem. Biotech., 60: 115-122. DOI: $10.1007 / \mathrm{BF} 02788066$

Pramod, T. and K. Lingappa, 2008. Immobilization of Aspergillus niger in polyurethane foam for citric acid production from carob pod extract. Am. J. Food Technol., 3: 252-256. DOI: 10.3923/ajft.2008.252.256
Pridham, T.G., P. Anderson, C. Foley, L.A. Lindenfelser and C.W. Hesseltine et al., 2002. Nocardiopsis metallicus sp. Nov. a metal-leaching actinomycetes isolated from an alkaline slag dump. Int. J. Syst. Evol. Microbiol., 52: 2291-2295. DOI: 10.1099/ijs.0.02279-0

Schippers, A., K. Bosecker, S. Willscher, C. Sproer and P. Schumann et al., 2002. Nocardiopsis metallicus sp. Nov. a metal-leaching actinomycetes isolated from an alkaline slag dump. Int. J. Syst. Evol. Microbiol., 52: 2291-2295. DOI: 10.1099/ijs.0.02279-0

Sen, S. and T. Satyanarayana, 1993. Optimization of alkaline protease production by thermophilic Bacillus licheniformis S-40. Indian J. Microbiol., 33: 43-47.

Sinha, S. and T. Satyanarayana, 1991. Alkaline protease production by Bacillus licheniformis. Indian J. Microbiol., 31: 425-430.

Tsuchiya, 1997. Cloning and expression of an intercellular alkaline protease gene from alkalophilic Thermoactinomyces sp. H5682. Biosci. Biotechnol. Biochem., 61: 298-303.

Yang, S.S. and C.M. Lee, 2001. Effect of culture media on protease and oxytetracycline production with mycelium and protoplasts of Streptomyces rimosus. World J. Microbiol. Biotechnol., 17: 403-410. DOI: 10.1023/A:1016759611127

Yang, S.S. and J.Y. Wang, 1999. Protease and amylase production of Streptomyces rimosus in submerged and solid state cultivation. Bot. Bull. Acad. Sin., 40: 259-265.

Yegneswaran, P.K. and M.R. Gray, 1991. Experimental simulation of dissolved oxygen fluctuations in large fermentors: Effect on Streptomyces clavuligerus. Biotechnol. Bioeng., 38: 1203-1209. DOI: 10.1002/bit.260381012

Yeoman, K.H. and C. Edwards, 1994. Protease production by Streptomyces thermovulgaris grown on rapemeal-derived media. J. Applied Bacteriol., 77: 264-270. DOI: $10.1111 /$ j.13652672.1994.tb03073.x 